\title{
Treatment of aseptic osteonecrosis of the talus. A draft of clinical guidelines
}

\author{
A.N. Torgashin, A.K. Mursalov, S.S. Rodionova, N.V. Zagorodniy
}

National Medical Research Center of Traumatology and Orthopedics n.a. N.N. Priorov, Moscow, Russian Federation

\begin{abstract}
Clinical guidelines are an algorithm adapted for use in our country, based on the works systematized by the level of evidence, reflecting current approaches to the diagnosis and treatment of aseptic bone necrosis (osteonecrosis) of various localizations. Purpose of the study Creation of an algorithm for diagnosis and treatment of osteonecrosis based on the assessment of the evidence level of literature data. Material and methods The Guidelines are a systematized algorithm based on the level of evidence for the management of patients with osteonecrosis, reflecting current approaches to diagnosis, treatment and rehabilitation, which are based on literature data and the authors' own experience. Electronic databases of Medline, Embase, Web of Science, and Cochrane Library platforms were searched for related sources. Preference was given to the works with high levels of evidence. References to information sources are given in the order of their appearance in the text. The search depth was 50 years due to the availability of systematic literature reviews in the framework of previous international clinical guidelines. When specific medical procedures related to the diagnosis, conservative or surgical treatment of osteonecrosis were included in the clinical recommendations, their level of evidence was reliability, the appropriateness of their use, taking into account the unified scale for assessing the quality of evidence and the strength of the recommendations for application of medical technologies GRADE. Results The Guidelines reflect aspects of clinical, instrumental and laboratory examination of patients with osteonecrosis, treatment options depending on the location of the process and disease stage. Conclusion Clinical recommendations on the medical assistance to patients with aseptic osteonecrosis have been compiled according to the requirements imposed on clinical recommendations developed by medical professional non-profit institutions.
\end{abstract}

Keywords: osteonecrosis, aseptic necrosis, clinical guidelines, osteonecrosis of the talus

In everyday clinical practice, situations may arise when the physician has nothing to rely on in making clinical decisions on the treatment of a particular pathology. It is due not only to the rapidly changing tactics of treating patients and the emergence of new methods and drugs, but also to the lack of clinical guidelines for a specific nosology. The physician is forced to either go beyond the legal framework, prescribing drugs off label, or to be limited to the minimum set of available drugs. The danger of such a situation for health care in general is quite clear. Therefore, the development of national clinical guidelines, which should be based on the studies of a high level of evidence, is a priority in the development of domestic medicine.

The use of modern methods of diagnosis and treatment of diseases based on clinicalrecommendations not only improves the quality of life of patients and reduces the risk of developing permanent or temporary disability, but also significantly reduces government spending on the treatment of the diseases in advanced stages. Clinical guidelines combine not only the latest effective developments in diagnosis and treatment, but also take into account the peculiarities of the country's health care system.

Aseptic bone necrosis is a serious disease that can be cured with adequate therapy if detected early. Late diagnosis and lack of therapy lead to rapid destruction of the adjacent joint and patient's disability.
Leading specialists (traumatologists, rheumatologists, radiologists) who directly face osteonecrosis in practice and see an urgent need for a clear and understandable algorithm for working with such patients took part in the development of the clinical guidelines draft. The treatment experience for osteonecrosis by colleagues from other countries as well as the available German and Chinese clinical guidelines were also considered. The proposed draft of guidelines is part of the National Clinical Guidelines for Aseptic Bone Necrosis (Osteonecrosis) and includes pharmacotherapy, surgery, and stage-specific rehabilitation.

Pharmacotherapy aimed at normalizing impaired bone metabolism, improving blood supply to the affected area, if necessary, is supplemented by surgical intervention, which requires an interdisciplinary approach that combines the work of a trauma surgeon, rheumatologist and other specialists [1].

Aseptic bone necrosis (osteonecrosis) is a severe polyetiological disease associated with the death of bone cells in a certain area of bone tissue, with impaired blood supply, rapidly leading to the development of secondary arthrosis/arthritis of the adjacent joint [2]. The most common localization is the head of the femur, the second most common are the condyles of the femur and tibia, less common is the head of the humerus and the talus [3]. Secondary aseptic necrosis (M87.3) is more common than idiopathic (M87.0). The cause of secondary aseptic necrosis, including the 
talus, may be the intake of glucocorticoids (M87.1), alcohol intoxication, radiation or chemotherapy, various coagulopathies (disseminated intravascular coagulation, thrombophilia), systemic diseases (SLE, vasculitis), sickle cellular anemia (M90.4), HIV, hyperlipidemia, liver disease and liver failure, diving and other hyperbaric conditions (M90.3).

Aseptic necrosis (AN) of the talus, in comparison with other localizations, frequently develops as a consequence of trauma (M87.2) [4]. Idiopathic osteonecrosis, the cause of which remains unclear, accounts for up to $40 \%$ of all cases of the disease. A number of authors assign a special role to a local increase in bone resorption and systemic osteoporosis $[5,6,7]$. Increased bone resorption in the lesion focus has been considered as a key point in the pathogenesis of osteonecrosis $[8,9,10]$. The relationship of aseptic necrosis with imbalance between bone formation and resorption, with the latter prevailing, has been confirmed by histomorphometry in an experimentally induced osteonecrosis [10, 11]. These deviations reduce the strength of the bone, which, under load, leads to an increase in the number of trabecular microfractures [12] that compress small vessels. Due to mechanical compression of the vascular bed, venous and then arterial stasis occurs, which is determined by measuring the intraosseous pressure and intramedullary venography. A decrease in blood flow resulting from increased bone marrow pressure is characteristic of the early stages of AN. [13, 14]. According to the English Registry, the incidence of osteonecrosis in the UK population ranged from 1.4 to 3.0 per 100,000 of population between 1989 and 2003. Moreover, the head of the femur was affected in $75.9 \%$ [15]. In Russia, aseptic necrosis has been disregarded in the structure of the musculoskeletal system diseases of the adult population. Moreover, there is no data on the incidence of aseptic necrosis of the talus.

Aseptic necrosis develops rapidly. However, if the disease is detected early, the prognosis is more favorable and conservative treatment yields good results and may preserve the function of the joint.

Purpose of the study Creation of an algorithm for the diagnosis and treatment of aseptic bone necrosis based on an assessment of the literature in regard to the level of evidence

\section{Design}

Methods used to collect / select evidence: search in electronic databases. The preference was given to works that could be attributed to a high level of reliable evidence.

References to information sources are given in the order of their appearance in the text.
Description of the methods used to assess the quality and strength of the evidence: The evidence base for the recommendations is publications included in Medline, Embase, Web of Science, and Cochrane Library. The search depth is 50 years, due to the availability of systematic literature reviews within the framework of previous international clinical guidelines.

Methods used to assess the quality and strength of evidence: expert consensus, assessment of reliability according to the rating scale.

Methods used to analyze evidence: reviews of published meta-analyses, systematic reviews with tables of evidence.

Description of the methods used to analyze the evidence: For selecting publications as potential sources of evidence, the methodology used in each study was examined separately to assess its validity. The outcome of the study influences the level of evidence assigned to the publication, which in turn has an effect on the level of reliability of the recommendations.

To minimize potential errors, each study was evaluated independently.

Tables of evidence were filled in by the authors of clinical guidelines: All information is ranked according to the level of evidence in these clinical guidelines (Tables 1,2) depending on the number and quality of studies on this issue.

Good Practice Points (GPPs): Recommended good practice is based on the clinical experience of the guideline authors.

Economic Analysis: No cost analysis has been performed and publications on pharmacological economics have not been reviewed.

Validation method of recommendations: external peer review, internal peer review.

Description of the validation method for recommendations: These guidelines have been peerreviewed by independent experts in draft versions, who were asked to comment on the understanding of the interpretation of the evidence on which the guidelines are based.

All comments received from the experts were carefully systematized and discussed by the members of the working group (the authors of the recommendations).

Each item was discussed separately.

Consultation and expert assessment: The draft of guidelines was peer-reviewed by independent experts, who were primarily asked to comment on the clarity and accuracy of the interpretation of the evidence for the recommendations. 
Working group: The recommendations were reanalyzed by the members of the working group in final revision and quality control. It was concluded that all the comments and remarks of the experts were taken into account; the risk of systematic errors in the development of the recommendations was minimized.

Basic recommendations: The level of reliability (strength) of the recommendations (Table 3) based on the levels of evidence is given at the end of each recommendation.

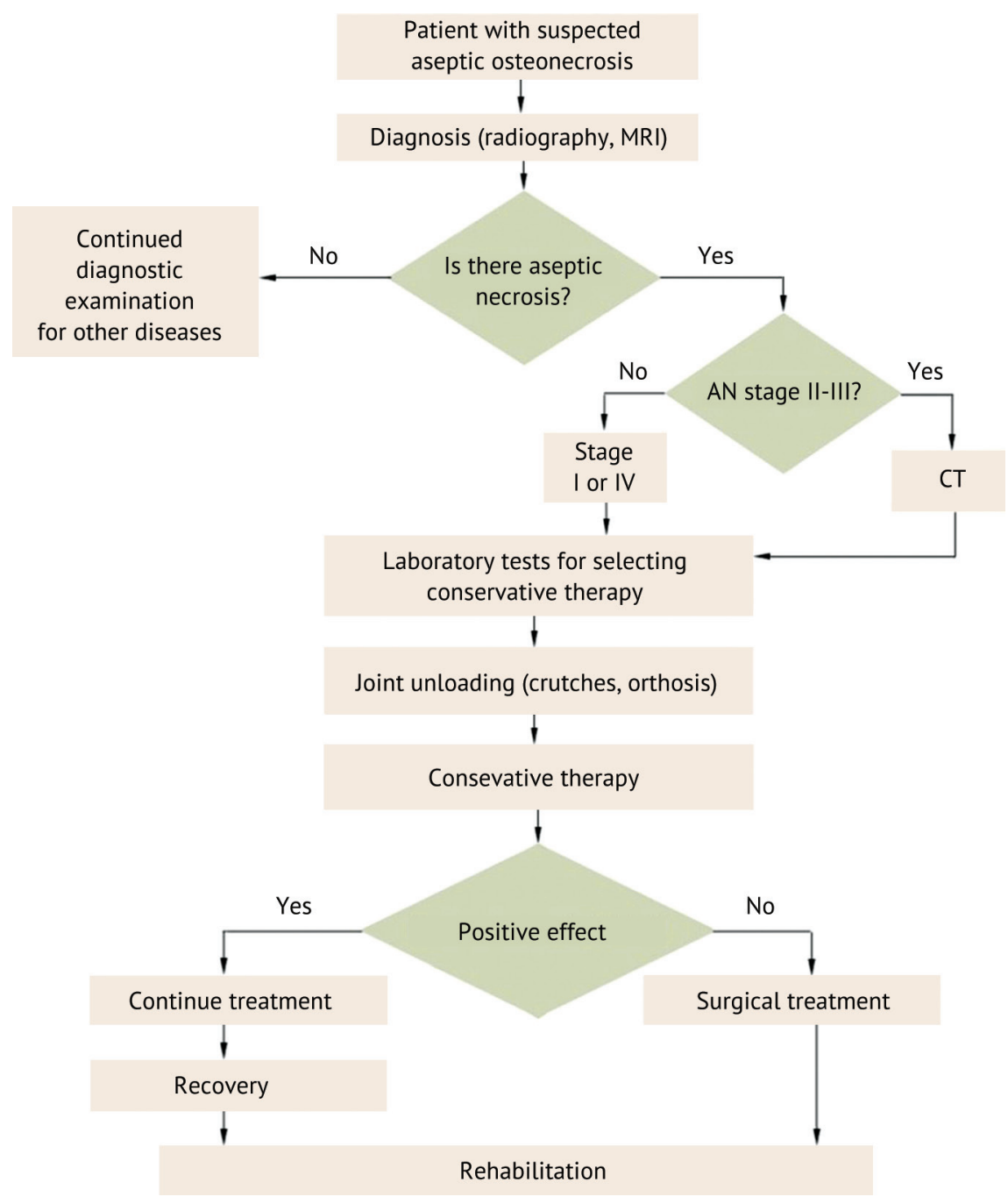

Fig. 1 Physician actions algorhithm

Table 1

Scale for evaluation of the level of evidence (LE) for methods of diagnosis (diagnostic interventions)

\begin{tabular}{|c|l|}
\hline LE & \multicolumn{1}{|c|}{ Explanation } \\
\hline 1 & $\begin{array}{l}\text { Systematic reviews of the studies with reference method control or systematic reviews of randomized clinical studies based } \\
\text { on meta-analysis }\end{array}$ \\
\hline 2 & $\begin{array}{l}\text { Separate studies with reference method control or separate randomized clinical studies and systematic reviews of any design, } \\
\text { with exception of randomized clinical studies utilizing meta-analysis }\end{array}$ \\
\hline 3 & $\begin{array}{l}\text { Studies without sequential control with reference method or studies with reference method that are not independent from the } \\
\text { method investigated or non-randomized comparative studies, including cohort studies }\end{array}$ \\
\hline 4 & Studies without comparison, clinical reports \\
\hline 5 & Only based on substantiation of the mechanism of action or expert opinion \\
\hline
\end{tabular}

Scale for evaluation of the level of evidence (LE) for methods of prevention, treatment and rehabilitation (preventive, therapeutic and rehabilitative interventions)

\begin{tabular}{|c|l|}
\hline LE & \multicolumn{1}{|c|}{ Explanation } \\
\hline 1 & Systematic reviews of RCS with the use of meta-analysis \\
\hline 2 & Separate RCS and systematic reviews of the studies of any design, excluding RCS, with the use of meta-analysis \\
\hline 3 & Non-randomized comparative studies, including cohort studies \\
\hline 4 & Non-comparative studies, case reports or series of cases, studies of case-control type \\
\hline 5 & Only a substantiation of the mechanism of intervention (pre-clinical studies) or expert opinions \\
\hline
\end{tabular}


Scale for evaluation of the level of reliability (LR) for methods of prevention, treatment and rehabilitation (preventive, therapeutic and rehabilitative interventions)

\begin{tabular}{|c|l|}
\hline LR & \multicolumn{1}{|c|}{ Explanation } \\
\hline A & $\begin{array}{l}\text { Strong recommendation (all the criteria of effectiveness (outcomes) are important; all studies have high or satisfactory } \\
\text { methodological quality, their conclusions on the outcomes of interest are coordinated) }\end{array}$ \\
\hline B & $\begin{array}{l}\text { Relative recommendation (all the criteria of effectiveness (outcomes) are important; not all studies have high or satisfactory } \\
\text { methodological quality, and/or their conclusions on the outcomes of interest are not coordinated) }\end{array}$ \\
\hline C & $\begin{array}{l}\text { Weak recommendation: no evidence of required quality (all the criteria of effectiveness (outcomes) are not important; all } \\
\text { studies have low methodological quality, their conclusions on the outcomes of interest are not coordinated) }\end{array}$ \\
\hline
\end{tabular}

\section{Clinical examination}

The analysis of the clinical condition in patients with aseptic necrosis includes physical examination with evaluation of pain on the visual analogue scale (VAS) and of the ankle function and assessment of the disease stage in radiographic and MRI images.

Comment In the acute period, patients complain of pain in the area of the joint increasing by passive or active movements and axial loading [16].

Soft tissue swelling in the area of the joint and red skin may not be present. Skin temperature in the joint zone remains normal or slightly high. In contrast to osteoarthritis, pain prevails over the clinical condition in aseptic necrosis and does not correspond to the radiographic changes. Pain starts unexpectedly, often in good general condition. Patients usually recall a history of trauma to the ankle joint though it might be mild. The effect of non-steroid anti-inflammatory drugs is short in time or absent. In late stages of the disease when there is impression of joint surfaces and secondary osteoarthritis, pain may be persistent and the joint movements are significantly restricted.

A six-stage classification of Anderson based on MRI and CT data [17], a five-stage classification of Heppe [18] based in MTI study, a three-stage classification of Pritsch [19] based on the damage to hyaline cartilage revealed by arthroscopic study of the ankle joint or a more complex classification of Mintz [20] that includes not only the magnitude of damage but also its location, fragment stability or its displacement can be used for diagnosis of aseptic necrosis of the talus for choosing treatment tactics and prognosis.
However,ARCO (Association Research Circulation Osseous) classification has been recommended for unification and simplicity in evaluating the severity of femoral head osteonecrosis that is sufficiently universal for any location defining the stage of the disease that determines the treatment tactics [21].

\section{Level of recommendation reliability $C$ (level of} evidence 5)

Comment ARCO classification [22] includes four main stages of the disease (Table 4). The damage is analyzed by evaluating the articular surface and subchondral bone in the corresponding localization based on radiography, MRI and CT.

\section{Laboratory diagnosis}

Laboratory tests (clinical blood test, biochemical analysis of blood and urine, coagulogram, blood parathyroid hormone) are recommended for differential diagnosis against other diseases of bone and joints and personified pharmacological correction of disorders in bone remodeling in the osteonecrosis zone [23, 24].

Level of recommendation reliability $B$ (level of evidence 3)

Comment In osteonecrosis, clinical laboratory blood tests and indices of calcium homeostasis are within the normal values.

Differential diagnosis of osteonecrosis is recommended against an impression fracture (S82.1, S72.4), osteochondritis dissecting (M93), transient bone edema (transient osteoporosis) (not in ICD-10), osteitis of bones in osteoarthritis and osteoarthrosis (M85.3), infectious arthritis /osteomyelitis (M86), tumor and tumorlike bone lesions (metastasis) (C79.5), systemic diseases (M30-M36), which also lead to joint damage [21, 25-27].

Table 4

ARCO (Association Research Circulation Osseous) Classification

\begin{tabular}{|c|c|c|c|c|c|c|}
\hline Stage & 0 & 1 & 2 & Early 3 & Late 3 & 4 \\
\hline Changes & $\begin{array}{l}\text { All } \\
\text { examinations } \\
\text { are normal }\end{array}$ & $\begin{array}{l}\text { Rg, CT show no } \\
\text { changes while MRI } \\
\text { and scintigraphy } \\
\text { reveal them }\end{array}$ & $\begin{array}{l}\text { No collapse, no } \\
\text { crescent moon } \\
\text { sign. Rg shows } \\
\text { sclerosis, focal } \\
\text { osteoporosis }\end{array}$ & $\begin{array}{l}\text { No collapse, } \\
\text { crescent moon } \\
\text { sign is present. Rg } \\
\text { shows increased } \\
\text { density of } \\
\text { subchondral bone }\end{array}$ & $\begin{array}{l}\text { Collapse of the } \\
\text { articular surface. } \\
\text { Rg shows } \\
\text { increased density } \\
\text { of articular surface }\end{array}$ & $\begin{array}{l}\text { Osteoarthritis, } \\
\text { narrowing of } \\
\text { the joint gap, } \\
\text { destruction of the } \\
\text { articular surface }\end{array}$ \\
\hline $\begin{array}{l}\text { Diagnostic } \\
\text { methods }\end{array}$ & $\begin{array}{l}\text { Rg, CT, } \\
\text { MRI, } \\
\text { scintigraphy }\end{array}$ & $\begin{array}{l}\text { MRI, scintigraphy } \\
\text { Quantitative } \\
\text { evaluation of lesion } \\
\text { only with the use } \\
\text { of MRI }\end{array}$ & $\begin{array}{l}\text { Rg, CT, MRI, } \\
\text { scintigraphy } \\
\text { Quantitative } \\
\text { evaluation of } \\
\text { lesion with the use } \\
\text { of MRI and Rg }\end{array}$ & $\begin{array}{l}\text { Only RG and } \\
\text { CT Quantitative } \\
\text { evaluation of lesion } \\
\text { with the use of Rg }\end{array}$ & $\begin{array}{l}\text { Only RG and } \\
\text { CT Quantitative } \\
\text { evaluation of lesion } \\
\text { with the use of Rg }\end{array}$ & Only Rg \\
\hline
\end{tabular}




\section{Level of recommendation reliability $C$ (level of evidence 4)}

Comment In case of detection of hypercalcemia and hypercalciuria, it will be necessary to exclude hyperparathyroid osteodystrophy, oncological pathology; hypocalcemia - osteomalacia; deviations in the level of parathyroid hormone (hyper- or hypoparathyroidism of various origins); increased ESR or deviations in the blood formula - exclusion of bone marrow pathology.

\section{Instrumental methods of study}

Standard radiography detects pathology only if sclerosis line between the healthy bone and osteonecrosis (ARCO stage 2) appears.

When the zone of aseptic necrosis is localized in the subchondral zone, stages 3 and 4 are manifested by deformation of the articular surface, crescent moon sign or signs of secondary deforming osteoarthritis of the joint (osteophytes, narrowing of the joint space, destruction of the articular surface and formation of bone cysts) [28].

Despite a low informative value of radiography in the early stages of the disease, it is recommended to perform it for differential diagnosis with other pathologies [28].

Level of recommendation reliability $C$ (level of evidence 4)

- MRI is recommended as the main method to detect the initial stages of the aseptic necrosis [9, 29].

Level of recommendation reliability $B$ (level of evidence 2)

Comment MRI shows bone edema in the subchondral zone in Stage 1 (ARCO). In stage 2, there is a hypoechoic line of sclerosis (in the T1 mode), delimiting the damaged area from the healthy bone. There is no impression of the articular surface. Around a limited area of osteonecrosis, as a rule, there is an edema of bone tissue, the severity of which depends on the duration of the disease. Depending on the collapse of the articular surface, the third stage in the ARCO classification is divided into early stage 3 with an impression (compaction) of the subchondral bone, a "crescent moon" sign with preservation of the articular surface and hyaline cartilage, and late stage 3 with collapse of the articular surface. Stage 4 is manifested by secondary osteoarthritis of the ankle joint, destruction of the articular surfaces or absence of a cartilaginous covering in the zone of aseptic necrosis. Synovitis and cystic remodeling of the subchondral bone are common.

Already in the early stages of aseptic necrosis, the internal structure and, as a result, the functional characteristics of the hyaline cartilage covering the articular surfaces are damaged. One of the current methods for detecting these disorders is MRI study using T2-mapping, which enables to assess the hydration of the hyaline cartilage [30].
- For better visualization of the subchondral bone impression, according to Stevens et al. [31], it is recommended to use computed tomography (CT) of the affected joint. It is more informative in decision making about the need for surgical treatment, the choice of the method of intervention, differential diagnosis between the early and late stage 3 , or control of the dynamics of the aseptic necrosis after surgery [32].

Level of recommendation reliability $B$ (level of evidence 3)

- Scintigraphy has lost its diagnostic value with the development of MRI. It is recommended to be used only for differential diagnosis in difficult cases [33].

Level of recommendation reliability $C$ (level of evidence 4)

-To detect the total loss of bone mineral density (BMD), it is recommended to use dual-energy X-ray densitometry (DEXD) [5, 34, 35].

\section{Level of recommendation reliability $B$ (level of evidence 3)}

Comment The loss in BMD may not be the cause of osteonecrosis, but in some cases, osteonecrosis develops due to osteoporosis or osteopenia. BMD deficiency can influence the tactics and duration of conservative therapy and the prognosis of the course of the disease $[5,34,35]$.

\section{Conservative treatment}

Given the multifactorial nature of the condition, conservative therapy includes unloading the joint in combination with the administration of pain-killers, osteotropic therapy, anti-resorptive or anabolic drugs, vascular therapy, intra-articular injections and physiotherapy. The use of drugs as monotherapy is less effective.

In the early stages of the disease, it is recommended to unload the joint using crutches or a rigid orthosis on the ankle joint and a cane in the arm opposite to the affected limb for a period of at least three months [36].

Level of recommendation reliability $C$ (level of evidence 4)

Comment Unloading the ankle joint in the early stages of aseptic necrosis is necessary to reduce the risk of articular surface impression, since walking [37] increases the load on the articular surface by 3.5 times, which in the presence of microfractures in the subchondral zone can be critical for the patient and lead to joint destruction. Walking on crutches or fixation of the ankle joint in a brace (orthosis) with rigid lateral supports in combination with a cane in the arm opposite to the lesion is recommended.

To relieve pain in patients with a high risk of gastrointestinal pathology, it is recommended to give preference to highly selective non-steroidal antiinflammatory drugs from the coxib group, in patients with a high risk of cardiovascular pathology - to non-selective NSAIDs (Naproxen up to $500 \mathrm{mg} /$ day) [38-40]. 
Level of recommendation reliability $B$ (level of evidence 2)

Comment If pain persists after the start of unloading, it is possible to prescribe non-steroidal anti-inflammatory drugs that are chosen taking into account patient's concomitant pathology.

Administration of injectable glucocorticoids is not recommended for pain relief in osteonecrosis due to the high risk of disease progression [41].

Level of recommendation reliability $B$ (level of evidence 3)

The basic therapy for osteonecrosis from the first days after the detection of the disease is daily intake of calcium supplements (500-1000 mg/day) in combination with colcalciferol**/ alfacalcidol** $[42,43]$.

\section{Level of recommendation reliability $B$ (level of} evidence 3)

Comment To restore bone tissue in osteonecrosis, the administration of calcium and colcalciferol**/

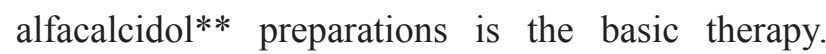
The unique role of calcium in providing bone tissue structure and regulation of intracellular processes by bone formation has been shown in numerous experimental and clinical studies [44].

When prescribing calcium preparations, the amount of salt containing $1000 \mathrm{mg}$ of $\mathrm{Ca}++$ is taken into account, therefore, calcium carbonate is most widely used in complex treatment.

An alternative to calcium carbonate salt is ossein, a hydroxyapatite complex, which contains calcium $178 \mathrm{mg}$ and phosphorus $82 \mathrm{mg}$. Calcium absorption in this case occurs without an abrupt rise in the level of ionized blood calcium [45]. D-hormone deficit (the term vitamin D is often used in the literature) [46] is often found in patients with various pathologies, including osteonecrosis of bones, especially in older and elderly people (its transport form is estimated - 25OHD). Lack of D-hormone leads to hypocalcemia and, consequently, to secondary hyperparathyroidism, by which the required amount of calcium is mobilized from the bone due to the activation of osteoclasts that destroy the bone, that reduces its strength properties. These disorders are the basis for prescribing vitamin $\mathrm{D}^{* *}$ preparations [47] in combination with calcium preparations to improve bone formation and quality [48].

The dosages of basic therapy drugs for the treatment of osteonecrosis are presented in Table 5.

If colecalciferol** is administered, the dose of the drug is prescribed according to the federal clinical guidelines "Osteoporosis" (at least 800 IU per day), under the control of blood vitamin D once every 3-6 months, with subsequent dose adjustment to achieve a level of at least $40 \mathrm{ng} / \mathrm{ml}$ [49].

In osteonecrosis of bones with the indication of the basic therapy (calcium carbonate/osseinhydroxyapatite complex and colecalciferol**/ alfacalcidol**) from the first days after the detection of the disease, anti-resorption drugs (bisphosphonates or \#denosumab**) are recommended [50-52].

\section{Level of recommendation reliability $B$ (level of} evidence 3)

Comment Bisphosphonates remain the main antiresorptive drugs. In the USA, according to the American Academy of Orthopedic Surgeons (AAOS), the proportion of bisphosphonates in the treatment of aseptic necrosis is $10 \%$ [50].

Their purpose is aimed at reducing the intensity of resorption both in the zone of osteonecrosis and in the surrounding bone tissue [53].

The use of anti-resorption drugs, preventing bone loss in the early stages of the disease, may reduce the risk of subchondral bone collapse [54].

This use of bisphosphonates has been shown in a number of studies. However, due to the absence in the indications to bisphosphonates of their possible use in aseptic necrosis, the administration of this group of drugs for osteonecrosis from a legal point of view may be off label. Oral bisphosphonates are often used, for example Alendronate** at a dose of $70 \mathrm{mg}$ per week [51]. One of its drawbacks is low compliance, and therefore the use of intravenous Zoledronic acid** 5 $\mathrm{mg}$ (once a year) has been considered more promising $[55,56]$. In addition to the direct anti-resorption effect and, consequently, the reduction of bone edema [55], bisphosphonates have a significant analgesic action, and thus improve the quality of life of patients [56, 57].

Initial dosage of calcium preparations and alfacalcidol (basic therapy) in osteonecrosis and dependence on the initial level of calcium in blood [42]

\begin{tabular}{|l|l|l|}
\hline Initial level of calcium in blood & \multicolumn{1}{|c|}{ Alfacalcidol dose ** } & \multicolumn{1}{c|}{ Dose of calcium preparations } \\
\hline $2.35 \mathrm{mmol} / \mathrm{L}$ and higher & $\begin{array}{l}0.5-0.75 \mu \mathrm{g} \text { daily for } 3 \mathrm{months} \text { and monitoring } \\
\text { of calcium levels every } 3 \mathrm{months} \text { for 1 year to } \\
\text { adjust the dose of the drug }\end{array}$ & $\begin{array}{l}\text { From the 1st day of treatment, ossein- } \\
\text { hydroxyapatite complex, one pill twice a day, } \\
\text { or a calcium preparation } 500-1000 \mathrm{mg} \text { per day } \\
\text { during the entire period of treatment }\end{array}$ \\
\hline $2.0-2.30 \mathrm{mmol} / \mathrm{L}$ & $\begin{array}{l}0.75-1.0 \mu \mathrm{g} \text { daily for } 3 \mathrm{months} \text { and control of } \\
\text { blood calcium once in } 3 \mathrm{months} \text { during the } \\
\text { entire treatment period }\end{array}$ & $\begin{array}{l}\text { hydroxyapatite complex, } 2 \text { pills twice a day for } \\
\text { the first } 3 \text { months, then one pill twice a day, or a } \\
\text { calcium preparation of } 500-1000 \text { mg during the } \\
\text { entire period of treatment }\end{array}$ \\
\hline
\end{tabular}


The use of a monoclonal antibody to RANKL

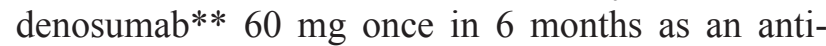
resorption drug has a smaller evidence base; however, the drug can be used to treat patients with a limited ability to BPs due to impaired nitrogen excretory function of the kidneys, as well as with ineffectiveness of bisphosphonates shown in the entire period of treatment [52]. The restoration of bone tissue in the early stages of aseptic necrosis may occur within three to 6 months of treatment. However, taking into account the peculiarity of bone metabolism in aseptic necrosis, the therapy for at least one year is recommended to reduce the risk of recurrence.

For anabolic therapy in patients with a low level of bone formation, it is recommended to administer teriparatide at a dose of $20 \mu \mathrm{g}$ subcutaneously once a day during the entire treatment period, but not more than for two years [58].

Level of recommendation reliability $B$ (level of evidence 3)

Comment A number of studies have shown the possibility of using anabolic therapy in the treatment of osteonecrosis of bones. For example, teriparatide is a drug that stimulates bone formation. Its effectiveness in osteonecrosis has been proven in a comparative study with alendronate [58].

To provide angioprotective and anti-aggregation effects, improvement of collateral blood flow, inhibition of platelet aggregation with increased microcirculation and reduction of the risk of arterial thrombosis, it is recommended to prescribe dipyridomol at a dose of $75 \mathrm{mg}$ per day for 3 weeks [59].

Level of recommendation reliability $B$ (level of evidence 3)

Comment Considering the fact that microcirculation is impaired primarily or secondarily in idiopathic osteonecrosis, dipyridomol is prescribed as an anti-aggregation agent and angioprotective agent from the first days upon the diagnosis as another component of treatment [60].

It is recommended to use iloprost at a dose of $20 \mu \mathrm{g} / \mathrm{ml}$ per day for 5 days as an anti-aggregation, angioprotective and vasodilation agent to improve microcirculation in the osteonecrosis zone [61, 62].

Level of recommendation reliability $B$ (level of evidence 3)

Comment Iloprost can be used as a vasodilator. It is an analogue of prostacyclins, reduces intraosseous pressureandimprovesthe state of themicrovasculature. It is injected daily and intravenously, as a 6-hour infusion into a peripheral vein or an inserted central catheter at an average rate of $0.5-2 \mathrm{ng} / \mathrm{kg} / \mathrm{min}$ using an infusion pump [61, 63]. This therapy should be carried out exclusively in a hospital or outpatient clinic with the presence of an intensive care team due to the high risk of blood pressure drop [61].
If osteonecrosis is associated with thrombophilia or hypofibrinolysis, in order to prevent the progression of the disease at ARCO stages 1-2, anticoagulants are recommended in a complex therapy, in particular, enoxyparin sodium** at a dose of $4000 \mathrm{IU}(0.4 \mathrm{ml})$ to $6000 \mathrm{IU}(0.6 \mathrm{ml})$ per day subcutaneously, for 2 to 12 weeks $[64,65]$.

Level of recommendation reliability $B$ (level of evidence 3)

Comment The combination of enoxyparin** with the drugs that influence hemostasis (salicylates of systemic action, acetylsalicylic acid in doses that have an anti-inflammatory effect, NSAIDs, including ketorolac, and thrombolytics such as alteplase, reteplase, streptokinase, tenecteplase, urokinase) is associated with a high risk of gastrointestinal bleeding, and therefore it is recommended to cancel them before starting therapy with enoxyparin**. When the forced combination of enoxyparin** with inhibitors of platelet aggregation (dipyridomol) or acetylsalicylic acid in doses that have an antiaggregation effect (cardioprotection), caution and careful clinical observation with monitoring of laboratory parameters should be performed [66].

Considering the fact that there is an increase in the level of chondroitin sulfate in the synovial fluid of patients with aseptic necrosis, which confirms the destruction of the hyaline cartilage [67] even in the early stages of the disease, the use of chondroitin and glucosamine preparations is recommended [68].

Level of recommendation reliability $C$ (level of evidence 4)

Intra-articular ozone therapy may be an effective method to reduce synovitis and improve joint trophism. It is recommended at the initial stages of osteonecrosis, with preserved articular surface and hyaline cartilage [69].

\section{Level of recommendation reliability $C$ (level of evidence 4)}

Comment The use of medical ozone is based on its ability to quickly relieve pain and improve joint mobility. The spread of the method was facilitated by the absence of its side effects [70-72]. According to the available data [69], in some cases, the combination of ozone therapy with hyaluronic acid preparations or platelet-rich plasma increases the therapeutic effect of the latter $[73,74]$.

\section{Surgical treatment}

At ARCO stages 1-2 of osteonecrosis of the talus, tunneling (decompression) of the lesion is recommended if pain persists not earlier than three months after the start of conservative treatment [36].

Level of recommendation reliability $B$ (level of evidence 2)

Comment In patients with stages 1-2 of aseptic necrosis of the talus, the clinical effect of 
decompression has been proven. However, it should be used no earlier than three months after the start of conservative therapy and only if there is no effect from the latter [36]. The use of tunneling at an earlier date can enhance resorption and lead to the progression of the disease. The procedure is performed as minimally invasive under the control of an image intensifier [75]. A combination of decompression of the talus with intraosseous injection of biologically active substances that stimulate remodeling processes is possible.

At ARCO stage 3 of osteonecrosis of the talus, it is recommended to perform bone plasty of the focus in combination with previously prescribed conservative therapy [76].

\section{Level of recommendation reliability $B$ (level of evidence 3)}

Comment It is possible to perform bone plasty both with a vascularized autograft on a vascular pedicle from the condyle of the femur or from the cuboid bone of the foot, and non-vascularized autograft from the iliac crest or heel bone. The main purpose of plasty is to maintain the architectonics of the talus. Vascularized grafting may increase the blood flow in the area of aseptic necrosis [76].

In ARCO stages 3-4 of osteonecrosis of the talus if its structure is preserved and there is secondary arthritis, ankle arthroplasty is recommended [77].
Level of recommendation reliability $B$ (level of evidence 3)

Comment Ankle arthroplasty [77] can be performed only if the normal architecture of the talus is preserved. Otherwise, the rate of revision interventions increases significantly due to component instability [78].

At stage 4 of osteonecrosis, in lysis of the talus, it is recommended to consider the possibility of its partial or complete prosthetics [79].

Level of recommendation reliability $C$ (level of evidence 4)

Comment There is total prosthetic replacement when the entire bone is replaced, and partial prosthetics, in which, depending on the severity of damage, certain anatomical areas are replaced [79].

Preparation of an implant for prosthetics of the talus is performed on the basis of $3 \mathrm{D}$ reconstruction of the results of computed tomography of the contralateral ankle joint. In partial prosthetics, it is possible to use special implants aimed at replacing a part of the talus defect.

In the presence of valgus or varus deformity of more than 15 degrees and the need to correct angular deformities, arthrodesis of the ankle joint (tibio-calcaneal arthrodesis or Blair arthrodesis) is recommended [80, 81].

\section{Level of recommendation reliability $B$ (level of evidence 3)}

\section{CONCLUSION}

Clinical guidelines for the provision of medical care to patients with aseptic bone necrosis have been drawn up in accordance with the requirements for the development of clinical guidelines by medical professional non-profit organizations, part 2 of article 76 of the Federal Law of November 21, 2011, No.
323 - FL "On the basics of protecting the health in the citizens in the Russian Federation". Clinical guidelines have been based on evidence-based clinical experience describing the actions of a physician in the diagnosis, differential diagnosis, treatment, rehabilitation and prevention of osteonecrosis.

\section{REFERENCES}

1. Malizos K.N., Karantanas A.H., Varitimidis S.E., Dailiana Z.H., Bargiotas K., Maris T. Osteonecrosis of the femoral head: etiology, imaging and treatment. Eur. J. Radiol., 2007, vol. 63, no. 1, pp. 16-28. DOI: 10.1016/j.ejrad.2007.03.019.

2. Ilinykh E.V., Barskova V.G., Lidov P.I., Nasonov E.L. Osteonekroz. Chast 1. Faktory riska i patogenez [Osteonecrosis. Part 1. Risk factors and pathogenesis]. Sovremennaia Revmatologiia, 2013, no. 1, pp. 17-24. (in Russian)

3. Mankin H.J. Nontraumatic necrosis of bone (osteonecrosis). N. Engl. J. Med., 1992, vol. 326, no. 22, pp. 1473-1479. DOI: 10.1056/ NEJM199205283262206.

4. Canale S.T., Belding R.H. Osteochondral lesions of the talus. J. Bone Joint Surg. Am., 1980, vol. 62, no. 1, pp. 97-102.

5. Yamamoto T., Bullough P.G. Spontaneous osteonecrosis of the knee: the result of subchondral insufficiency fracture. J. Bone Joint Surg. Am., 2000, vol. 82, no. 6, pp. 858-866. DOI: 10.2106/00004623-200006000-00013.

6. Varoga D., Drescher W., Pufe M., Groth G., Pufe T. Differential expression of vascular endothelial growth factor in glucocorticoid-related osteonecrosis of the femoral head. Clin. Orthop. Relat. Res., 2009, vol. 467, no. 12, pp. 3273-3282. DOI: 10.1007/s11999-009-1076-3.

7. Mont M.A., Jones L.C, Hungerford D.S. Nontraumatic osteonecrosis of the femoral head: ten years later. J. Bone Joint Surg. Am., 2006, vol. 88, no. 5, pp. 1117-1132. DOI: 10.2106/JBJS.E.01041.

8. Aya-ay J., Athavale S., Morgan-Bagley S., Bian H., Bauss F., Kim H.K. Retention, distribution, and effects of intraosseously administered ibandronate in the infarcted femoral head. J. Bone Miner. Res., 2007, vol. 22, no. 1, pp. 93-100. DOI: 10.1359/jbmr.060817.

9. Bowers J.R., Dailiana Z.H., McCarthy E.F., Urbaniak J.R. Drug therapy increases bone density in osteonecrosis of the femoral head in canines. J. Surg. Orthop. Adv., 2004, vol. 13, no. 4, pp. 210-216.

10. Kim H.K., Morgan-Bagley S., Kostenuik P. RANKL inhibition: a novel strategy to decrease femoral head deformity after ischemic osteonecrosis J. Bone Miner. Res., 2006, vol. 21, no 12, pp. 1941-1954. DOI: 10.1359/jbmr.060905.

11. Yang J., Wang L., Xu Y., Fan K., Wang J. An experimental osteonecrosis of femoral head induced by a combination of a single low-dose lipopolysaccharide and methylprednisone. Zhongguo Xiu Fu Chong Jian Wai Ke Za Zhi, 2008, vol. 22, no. 3, pp. 271-275. (in Chinese)

12. Steffen R.T., Athanasou N.A., Gill H.S., Murray D.W. Avascular necrosis associated with fracture of the femoral neck after hip resurfacing: histological assessment of femoral bone from retrieval specimens. J. Bone Joint Surg. Br., 2010, vol. 92, no. 6, pp. 787-793. DOI: 10.1302/0301620X.92B6.23377.

13. Smirnov A.V. Rentgenologicheskaia diagnostika porazheniia tazobedrennykh sustavov pri revmaticheskikh zabolevaniiakh [X-ray diagnosis of the hip involvement in rheumatic diseases]. Consilium Medicum, 2003, vol. 5, no. 8, pp. 442-446. (in Russian)

14. Hungerford D.S., Lennox D.W. The importance of increased intraosseous pressure in the development of osteonecrosis of the femoral head: implications for treatment. Orthop. Clin. North Am., 1985, vol. 16, no. 4, pp. 635-654. 
15. Cooper C., Steinbuch M., Stevenson R., Miday R., Watts N.B. The epidemiology of osteonecrosis: findings from the GPRD and THIN databases in the UK. Osteoporos. Int., 2010, vol. 21, no. 4, pp. 569-577. DOI: 10.1007/s00198-009-1003-1

16. Ito H., Matsuno T., Minami A. Relationship between bone marrow edema and development of symptoms in patients with osteonecrosis of the femoral head. AJR Am. J. Roentgenol., 2006, vol. 186, no. 6, pp. 1761-1770. DOI: 10.2214/AJR.05.0086.

17. Anderson I.F., Crichton K.J., Grattan-Smith T., Cooper R.A., Brazier D. Osteochondral fractures of the dome of the talus. J. Bone Joint Surg. Am., 1989, vol. 71, no. 8, pp. 1143-1152.

18. Hepple S., Winson I.G., Glew D. Osteochondral lesions of the talus: a revised classification. Foot Ankle Int., 1999, vol. 20, no. 12, pp. 789-793. DOI: $10.1177 / 107110079902001206$.

19. Pritsch M., Horoshovski H., Farine I. Arthroscopic treatment of osteochondral lesions of the talus. J. Bone Joint Surg. Am., 1986, vol. 68, no. 6, pp. $862-865$.

20. Mintz D.N., Tashjian G.S., Connell D.A., Deland J.T., O'Malley M., Potter H.G. Osteochondral lesions of the talus: a new magnetic resonance grading system with arthroscopic correlation. Arthroscopy, 2003, vol. 19, no. 4, pp. 353-359. DOI: 10.1053/jars.2003.50041.

21. Grieser T. Atraumatische und aseptische Osteonekrose großer Gelenke [Atraumatic and aseptic osteonecrosis of large joints]. Radiologe, 2019, vol. 59, no. 7, pp. 647-662. (in German) DOI: 10.1007/s00117- 019-0560-3.

22. Gardeniers J.V.M. Report of the Committee of Staging and Nomenclature. ARCO News Letter, 1993, vol. 5, no. 2, pp. 79-82.

23. Singer F.R., Eyre D.R. Using biochemical markers of bone turnover in clinical practice. Cleve. Clin. J. Med., 2008, vol. 75, no. 10, pp. 739-750. DOI: $10.3949 /$ ccjm. 75.10 .739 .

24. Epstein S. Serum and urinary markers of bone remodeling: assessment of bone turnover. Endocr. Rev., 1988, vol. 9, no. 4, pp. 437-449. DOI: 10.1210/ edrv-9-4- 437.

25. Pivec R., Johnson A.J., Harwin S.F., Mont M.A. Differentiation, Diagnosis, and Treatment of Osteoarthritis, Osteonecrosis, and Rapidly Progressive Osteoarthritis. Orthopedics, 2013, vol. 36, no. 2, pp. 118-125. DOI: 10.3928/01477447-20130122-04.

26. Ragab Y., Emad Y., Abou-Zeid A. Bone marrow edema syndromes of the hip: MRI features in different hip disorders. Clin. Rheumatol., 2008, vol. 27 , no. 4, pp. 475-482. DOI: 10.1007/s10067-007-0731-x.

27. Narváez J., Narváez J.A., Rodriguez-Moreno J., Roig-Escofet D. Osteonecrosis of the knee: differences among idiopathic and secondary types. Rheumatology (Oxford), 2000, vol. 39, no. 9, pp. 982-989. DOI: 10.1093/rheumatology/39.9.982.

28. Sun W., Li Z.R., Yang Y.R., Shi Z.C., Wang B., Liu B., Shi S. Experimental study on phase-contrast imaging with synchrotron hard X-ray for repairing osteonecrosis of the femoral head. Orthopedics, 2011, vol. 34, no. 9, pp. e530-e534. DOI: 10.3928/01477447-20110714-07.

29. Cegarra Navarro M.F., Martínez Fernández M., Blanco Barrio A., Lloret Estañ F. Resonancia magnética de la osteonecrosis espontánea de la rodilla: ¿existe un proceso agudo o crónico predisponente? [Can MRI determine whether acute or chronic processes predisposing conditions are present in spontaneous osteonecrosis of the knee?]. Radiologia, 2010, vol. 52, no. 3, pp. 234-240. (in Spanish) DOI: 10.1016/j.rx.2009.12.013.

30. Patel R., Eltgroth M., Souza R., Zhang C.A., Majumdar S., Link T.M., Motamedi D. Loaded versus unloaded magnetic resonance imaging (MRI) of the knee: Effect on meniscus extrusion in healthy volunteers and patients with osteoarthritis. Eur. J. Radiol. Open, 2016, vol. 3, pp. 100-107. DOI: $10.1016 /$ j.ejro.2016.05.002.

31. Stevens K., Tao C., Lee S.U., Salem N., Vandevenne J., Cheng C., Neumann G., Valentin-Opran A., Lang P. Subchondral fractures in osteonecrosis of the femoral head: comparison of radiography, CT, and MR imaging. AJR Am. J. Roentgenol., 2003, vol. 180, no. 2, pp. 363-368. DOI: 10.2214/ ajr.180.2.1800363.

32. McCollough C.H., Leng S., Yu L., Fletcher J.G. Dual- and multi-energy CT: principles, technical approaches, and clinical applications. Radiology, 2015, vol. 276, no. 3, pp. 637-653. DOI: 10.1148/radiol.2015142631

33. Ryu K.N., Jin W., Park J.S. Radiography, MRI, CT, bone scan and PET-CT. In: Koo K.H., Mont M.A., Jones L.C., eds. Osteonecrosis. Heidelberg, Springer, 2014, pp. 179-195. DOI: 10.1007/978-3-642-35767-1 23.

34. Narváez J.A., Narváez J., De Lama E., Sánchez A. Spontaneous osteonecrosis of the knee associated with tibial plateau and femoral condyle insufficiency stress fracture. Eur. Radiol., 2003, vol. 13, no. 8, pp. 1843-1848. DOI: 10.1007/s00330-002-1775-6.

35. Horikawa A., Miyakoshi N., Shimada Y., Kodama H. Spontaneous Osteonecrosis of the Knee: A Retrospective Analysis by Using MRI and DEXA. Open Orthop. J., 2016, vol. 10, pp. 532-538. DOI:10.2174/1874325001610010532.

36. Gross C.E., Haughom B., Chahal J., Holmes G.B. Jr. Treatments for avascular necrosis of the talus: a systematic review. Foot Ankle Spec., 2014, vol. 7, no. 5, pp. 387-397. DOI: $10.1177 / 1938640014521831$.

37. Bergmann G., Graichen F., Rohlmann A. Hip joint forces during walking and running, measurement in two patients. J. Biomech., 1993, vol. 26, no. 8, pp. 969-990. DOI: 10.1016/0021-9290(93)90058-m

38. Reginster J.Y., Malmstrom K., Mehta A., Bergman G., Ko A.T., Curtis S.P., Reicin A.S. Evaluation of the efficacy and safety of etoricoxib compared with naproxen in two, 138-week randomised studies of patients with osteoarthritis. Ann. Rheum. Dis., 2007, vol. 66, no. 7, pp. 945-951. DOI: 10.1136/ ard.2006.059162.

39. Bruyère O., Honvo G., Veronese N., Arden N.K., Branco J., Curtis E.M., Al-Daghri N.M., Herrero-Beaumont G., Martel-Pelletier J., Pelletier J.P., Rannou F., Rizzoli R., Roth R., Uebelhart D., Cooper C., Reginster J.Y. An updated algorithm recommendation for the management of knee osteoarthritis from the European Society for Clinical and Economic Aspects of Osteoporosis, Osteoarthritis and Musculoskeletal Diseases (ESCEO). Semin. Arthritis Rheum., 2019, vol. 9, no. 3, pp. 337-350. DOI: 10.1016/j.semarthrit.2019.04.008.

40. Patrignani P., Tacconelli S., Bruno A., Sostres C., Lanas A. Managing the adverse effects of nonsteroidal anti-inflammatory drugs. Expert Rev. Clin. Pharmacol., 2011, vol. 4, no. 5, pp. 605-621. DOI: 10.1586/ecp.11.36.

41. Weinstein R.S. Glucocorticoid-induced osteonecrosis. Endocrine, 2012, vol. 41, no. 2, pp. 183-190. DOI: 10.1007/s12020-011-9580-0

42. Shumskii A.A. Diagnostika i farmakologicheskaia terapiia rannikh stadii asepticheskogo nekroza golovki bedrennoi kosti. Avtoref. dis. ... kand. med. nauk [Diagnosis and pharmacological therapy of the early stages of femoral head aseptic necrosis. Cand. med. sci. diss. abstr. ]. M., 2015, 24 p. (in Russian)

43. Mironov S.P., Rodionova S.S., Shumskii A.A., comp. Farmakologicheskaia terapiia rannikh stadii asepticheskogo nekroza golovki bedrennoi kosti: med. tekhnologiia [Pharmacological therapy of the early stages of femoral head aseptic necrosis: medical technology]. FSI CPITO of RosMedTechnologies. M., 2011, 11 p. (in Russian)

44. Varenna M., Binelli L., Casari S., Zucchi F., Sinigaglia L. Effects of dietary calcium intake on body weight and prevalence of osteoporosis in early postmenopausal women. Am. J. Clin. Nutr., 2007, vol. 86, no. 3, pp. 639-644. DOI: 10.1093/ajcn/86.3.639.

45. Buclin T., Jacquet A.F., Burckhardt P. Absorption intestinale de gluconate de calcium et de complexe osséino-minéral: évaluation par des dosages conventionnels [Intestinal absorption of calcium gluconate and oseine-mineral complex: an evaluation by conventional analyses]. Schweiz. Med. Wochenschr., 1986, vol. 116, no. 50, pp. 1780-1783. (in French)

46. Wacker M., Holick M.F. Sunlight and Vitamin D: A global perspective for health. Dermatoendocrinol., 2013, vol. 5, no. 1, pp. 51-108. DOI: 10.4161/ derm.24494.

47. Bischoff-Ferrari H.A., Dawson-Hughes B., Baron J.A., Burckhardt P., Li R., Spiegelman D., Specker B., Orav J.E., Wong J.B., Staehelin H.B., O'Reilly E., Kiel D.P., Willett W.C. Calcium intake and hip fracture risk in men and women: a meta-analysis of prospective cohort studies and randomized controlled trials. Am. J. Clin. Nutr., 2007, vol. 86, no. 6, pp. 1780-1790. DOI: 10.1093/ajen/86.5.1780.

48. Doetsch A.M., Faber J., Lynnerup N., Wätjen I., Bliddal H., Danneskiold-Samsøe B. The effect of calcium and vitamin D3 supplementation on the healing of the proximal humerus fracture: a randomized placebo-controlled study. Calcif. Tissue Int., 2004, vol. 75, no. 3, pp. 183-188. DOI: 10.1007/ s00223-004-0167-0

49. Melnichenko G.A., Belaia Zh.E., Rozhinskaia L.Ia., Toroptsova N.V., Alekseeva L.I., Biriukova E.V., Grebennikova T.A., Dzeranova L.K., Dreval A.V., Zagorodnii N.V., Ilin A.V, Kriukova I.V., Lesniak O.M., Mamedova E.O., Nikitinskaia O.A., Pigarova E.A., Radionova S.S., Skripnikova I.A., Tarbaeva N.V., Farba L.Ia., Tsoriev T.T., Chernova T.O., Iureneva S.V., Iakushevskaia O.V., Dedov I.I. Federalnye Klinicheskie Rekomendatsii po diagnostike, lecheniiu i profilaktike osteoporoza [Federal Clinical Recommendations on osteoporosis diagnosis, treatment and prevention]. Problemy Endokrinologii, 2017, vol. 63, no. 6, pp. 392-426. (in Russian) DOI: 10.14341/probl2017636392-426.

50. Ramachandran M. Ward K. Brown R.R., Munns C.F., Cowell C.T., Little D.G. Intravenous Bisphosphonate Therapy for Traumatic Osteonecrosis of the Femoral Head in Adolescents. J. Bone Joint Surg. Am. 2007, vol. 89, no. 8, pp. 1727-1734. DOI: 10.2106/JBJS.F.00964.

51. Chen C.H., Chang J.K., Lai K.A., Hou S.M., Chang C.H., Wang G.J. Alendronate in the prevention of collapse of the femoral head in nontraumatic osteonecrosis: a two-year multicenter, prospective, randomized, double-blind, placebo-controlled study. Arthritis Rheum., 2012, vol. 64, no. 5, pp. 1572-1578. DOI: 10.1002/art.33498.

52. Rolvien T., Schmidt T., Butscheidt S., Amling M., Barvencik F. Denosumab is effective in the treatment of bone marrow oedema syndrome. Injury, 2017, vol. 48, no. 4, pp. 874-879. DOI: 10.1016/j.injury.2017.02.020

53. Zywiel M.G., McGrath M.S., Seyler T.M., Marker D.R., Bonutti P.M., Mont M.A. Osteonecrosis of the knee: a review of three disorders. Orthop. Clin. North Am., 2009, vol. 40, no. 2, pp. 193-211. DOI: 10.1016/j.ocl.2008.10.010 
54. Karim A.R., Cherian J.J., Jauregui J.J., Pierce T., Mont M.A. Osteonecrosis of the knee: review. Ann. Transl. Med., 2015 , vol. 3, no. 1, pp. 6. DOI: 10.3978/j.issn.2305-5839.2014.11.13.

55. Agarwala S., Vijayvargiya M. Single Dose Therapy of Zoledronic Acid for the Treatment of Transient Osteoporosis of Hip. Ann. Rehabil. Med., 2019, vol. 43, no. 3, pp. 314-320. DOI: 10.5535/arm.2019.43.3.314.

56. Agarwala S., Vijayvargiya M. Bisphosphonate combination therapy for non-femoral avascular necrosis. J. Orthop. Surg. Res., 2019, vol. 14, no. 1, pp. 112. DOI: 10.1186/s13018-019-1152-7.

57. Cross M., Macara M., Little E., Chan M., Little D., Buchbinder R., Hill C.L., Duncan E., Inderjeeth C., Major G., Sambrook P., March L. Efficacy of zoledronate in treating osteonecrosis of femoral head: a randomized controlled trial. Osteoarthritis and Cartilage. Abstracts, 2018, vol. 26, no. Suppl. 1, pp. S309-S310. DOI: 10.1016/j.joca.2018.02.622.

58. Arai R., Takahashi D., Inoue M., Irie T., Asano T., Konno T., Terkawi M.A., Onodera T., Kondo E., Iwasaki N. Efficacy of teriparatide in the treatment of nontraumatic osteonecrosis of the femoral head: a retrospective comparative study with alendronate. BMC Musculoskelet. Disord., 2017, vol. 18, no. 1, pp. 24. DOI: 10.1186/s12891-016-1379-y.

59. Rodionova S.S., Shumskii A.A. Novyi podkhod k lecheniiu rannikh stadii asepticheskogo nekroza golovki bedrennoi kosti [A new approach to treating early stages of aseptic necrosis of the femoral head]. Tretii Rossiiskii Kongress po osteoporozu: sbornik tezisov [Proceedings of the ${ }^{\text {rd }}$ Russian Congress on Osteoporosis]. Ekaterinburg, 2008, p. 54. (in Russian)

60. Sung P.H., Yang Y.H., Chiang H.J., Chiang J.Y., Chen C.J., Yip H.K., Lee M.S. Cardiovascular and Cerebrovascular Events Are Associated With Nontraumatic Osteonecrosis of the Femoral Head. Clin. Orthop. Relat. Res., 2018, vol. 476, no. 4, pp. 865-874. DOI: 10.1007/ s11999.0000000000000161.

61. Claßen T., Becker A., Landgraeber S., Haversath M., Li X., Zilkens C., Krauspe R., Jäger M. Long-term Clinical Results after Iloprost Treatment for Bone Marrow Edema and Avascular Necrosis. Orthop. Rev. (Pavia), 2016, vol. 8, no. 1, pp. 6150. DOI: 10.4081/or.2016.6150.

62. Meizer R., Radda C., Stolz G., Kotsaris S., Petje G., Krasny C., Wlk M., Mayerhöfer M., Landsiedl F., Aigner N. MRI-controlled analysis of 104 patients with painful bone marrow edema in different joint localizations treated with the prostacyclin analogue iloprost. Wien Klin. Wochenschr., 2005, vol. 117, no. 7-8, pp. 278-286. DOI: 10.1007/s00508-005-0326-y.

63. Jäger M., Zilkens C., Bittersohl B., Matheney T., Kozina G., Blondin D., Krauspe R. Efficiency of iloprost treatment for osseous malperfusion. Int. Orthop., 2011, vol. 35, no. 5, pp. 761-765. DOI: 10.1007/s00264-010-0998-4.

64. Glueck C.J., Freiberg R.A., Sieve L., Wang P. Enoxaparin prevents progression of stages I and II osteonecrosis of the hip. Clin. Orthop. Relat. Res., 2005, no. 435, pp. 164-170. DOI: 10.1097/01.blo.0000157539.67567.03.

65. Beckmann R., Shaheen H., Kweider N., Ghassemi A., Fragoulis A., Hermanns-Sachweh B., Pufe T., Kadyrov M., Drescher W. Enoxaparin Prevents Steroid-Related Avascular Necrosis of the Femoral Head. Scientific World Journal, 2014, vol. 2014, pp. 347813. DOI: 10/1155/2014/347813.

66. Peck K.A., Calvo R.Y., Schechter M.S., Sise C.B., Kahl J.E., Shackford M.C., Shackford S.R., Sise M.J., Blaskiewicz D.J. The impact of preinjury anticoagulants and prescription antiplatelet agents on outcomes in older patients with traumatic brain injury. J. Trauma Acute Care Surg., 2014, vol. 76, no. 2, pp. 431-436. DOI: 10.1097/TA.0000000000000107.

67. Saito T., Takeuchi R., Mitsuhashi S., Uesugi M., Yoshida T., Koshino T. Use of joint fluid analysis for determining cartilage damage in osteonecrosis of the knee. Arthritis Rheum., 2002, vol. 46, no. 7, pp. 1813-1819. DOI: 10.1002/art.10367.

68. Fransen M., Agaliotis M., Nairn L., Votrubec M., Bridgett L., Su S., Jan S., March L., Edmonds J., Norton R., Woodward M., Day R.; LEGS study collaborative group. Glucosamine and chondroitin for knee osteoarthritis: a double-blind randomised placebo-controlled clinical trial evaluating single and combination regimens. Ann. Rheum. Dis., 2015, vol. 74, no. 5, pp. 851-858. DOI: 10.1136/annrheumdis-2013-203954.

69. Burmakova G.M., Savchenko A.M. Vnutrisustavnaia ozonoterapiia v kompleksnom lechenii koksartroza [Intraarticular ozone therapy in complex treatment of coxarthrosis]. Meditsinskii Sovet, 2011, vol. 7-8, pp. 35-38. (in Russian)

70. Iliakis E., Bonetti M., Iliakis A. Osteonecrosis of the femoral head: Could oxygen-ozone therapy became a treatment option? Journal of Ozone Therapy, 2015, vol. 1, no. 1. DOI: 10.7203/jo3t.1.1.2015.12163.

71. Siemsen C.H. Ozon-Anwendung bei akuten und chronischen Gelenkerkrankungen [Use of ozone in acute and chronic joint diseases]. Beck E.G., Viebahn-Hänsler R., eds. Ozon-Handbuch. Grundlagen. Prävention. Therapie [Ozone Handbook. Basics. Prevention. Therapy]. Landsberg/Lech: Ecomed, 1995, V-9.2 1 - V-9.2 14. (in German)

72. Torgashin A.N., Rodionova S.S., Torgashina A.V. Ozonoterapiia - nedootsenennye vozmozhnosti v lechenii zabolevanii krupnykh sustavov [Ozone therapy - underestimated possibilities in the treatment of large joint diseases]. Sovremennaia Revmatologiia, 2019, vol. 13, no. 3, pp. 126-129. (in Russian)

73. Invernizzi M., Stagno D., Carda S., Grana E., Picelli A., Smania N., Cisari C., Baricich A. Safety of intra-articular oxygen-ozone therapy compared to intra-articular sodium hyaluronate in knee osteoarthritis: A randomized single blind pilot study. Int. J. Phys. Med. Rehabil., 2017 , vol. 5, pp. 385. DOI: $10.4172 / 2329-9096.1000385$.

74. Giombini A., Menotti F., Di Cesare A., Giovannangeli F., Rizzo M., Moffa S., Martinelli F. Comparison between intrarticular injection of hyaluronic acid, oxygen ozone, and the combination of both in the treatment of knee osteoarthrosis. J. Biol. Regul. Homeost. Agents, 2016, vol. 30, no. 2, pp. 621-625.

75. Issa K., Naziri Q., Kapadia B.H., Lamm B.M., Jones L.C., Mont M.A. Clinical characteristics of early-stage osteonecrosis of the ankle and treatment outcomes. J. Bone Joint Surg. Am., 2014, vol. 96, no. 9, pp. e73. DOI: 10.2106/JBJS.M.00888.

76. Nunley J.A., Hamid K.S. Vascularized Pedicle Bone-Grafting from the Cuboid for Talar Osteonecrosis: Results of a Novel Salvage Procedure. J. Bone Joint Surg. Am., 2017, vol. 99, no. 10, pp. 848-854. DOI: 10.2106/JBJS.16.00841.

77. Lawton C.D., Butler B.A., Dekker R.G. 2nd, Prescott A., Kadakia A.R. Total ankle arthroplasty versus ankle arthrodesis - a comparison of outcomes over the last decade. Orthop. Surg. Res., 2017, vol. 12, no. 1, pp. 76. DOI: 10.1186/s13018-017-0576-1.

78. Braito M., Dammerer D., Kaufmann G., Fischler S., Carollo J., Reinthaler A., Huber D., Biedermann R. Are our expectations bigger than the results we achieve? A comparative study analysing potential advantages of ankle arthroplasty over arthrodesis. Int. Orthop., 2014, vol. 38, no. 8, pp. 16471653. DOI: 10.1007/s00264-014-2428-5.

79. Taniguchi A., Takakura Y., Tanaka Y., Kurokawa H., Tomiwa K., Matsuda T., Kumai T., Sugimoto K. An Alumina Ceramic Total Talar Prosthesis for Osteonecrosis of the Talus. J. Bone Joint Surg. Am., 2015, vol. 97, no. 16, pp. 1348-1353. DOI: 10.2106/JBJS.N.01272.

80. Yasui Y., Hannon C.P., Seow D., Kennedy J.G. Ankle arthrodesis: A systematic approach and review of the literature. World J. Orthop., 2016, vol. 7, no. 11, pp. 700-708. DOI: 10.5312/wjo.v7.i11.700.

81. Dhillon M.S., Rana B., Panda I., Patel S., Kumar P. Management Options in Avascular Necrosis of Talus. Indian J. Orthop., 2018, vol. 52, no. 3, pp. 284-296. DOI: 10.4103/ortho.IJOrtho_608_17.

Received: 13.07 .2020

\section{Information about the authors:}

1. Alexander N. Torgashin, M.D., Ph.D.,

National Medical Research Center of Traumatology and Orthopedics n.a. N.N. Priorov, Moscow, Russian Federation, Email: Dr.torgashin@gmail.com

2. Anatoly K. Mursalov, National Medical Research Center of Traumatology and Orthopedics n.a. N.N. Priorov, Moscow, Russian Federation, Email: tamerlanmursalov@gmail.com

3. Svetlana S. Rodionova, M.D., Ph.D., Professor,

National Medical Research Center of Traumatology and Orthopedics n.a. N.N. Priorov, Moscow, Russian Federation, Email: Rod06@inbox.ru

4. Nikolay V. Zagorodniy, M.D., Ph.D., Professor, correspondent member of RAS,

National Medical Research Center of Traumatology and Orthopedics n.a. N.N. Priorov, Moscow, Russian Federation 